\title{
Modeling and Control of Photovoltaic Panels Base Perturbation and Observation MPPT Method
}

\author{
Omid Palizban \\ Department of Electrical Engineering \\ University of Malaya, \\ Kuala Lumpur, Malaysia \\ Omid.palizban@siswa.um.edu.my
}

\author{
Saad Mekhilef \\ Department of Electrical Engineering \\ University of Malaya \\ Kuala Lumpur, Malaysia \\ Saad@um.edu.my
}

\begin{abstract}
Nowadays renewable energy is important and environmentally friendly, as it does not pollute and costs little. Solar energy is one of the main photovoltaic system types of energy. For those with no access to the main network due to geographical location, this kind of energy is beneficial and valuable in providing the needed electrical energy. This paper presents photovoltaic system modeling, temperature, its variation and irradiation, and how the system connects to the DC bus via a DC/DC converter. It has the ability to follow maximum power point tracking (MPPT) by a special control circuit, something useful in hybrid systems. Finally, an inverter is used to transfer power to the $\mathrm{AC}$ network and decrease the harmonic in the connection point.
\end{abstract}

Keywords-Solar Energy, PV Panel, P\&O method

I. NOMENCLATURE

\begin{tabular}{|c|c|}
\hline$I_{L}$ & Light current $[\mathrm{A}]$ \\
\hline$I_{O}$ & Saturation current $[\mathrm{A}]$ \\
\hline$I$ & Load current $[\mathrm{A}]$ \\
\hline$U$ & Output voltage [V] \\
\hline$R_{S}$ & Series resistance $[\Omega]$ \\
\hline 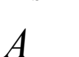 & Thermal voltage timing completion factor [V] \\
\hline$\varphi$ & Irradiance $\left[\mathrm{W} / \mathrm{m}^{2}\right]$ \\
\hline$\varphi_{r e f}$ & Reference irradiance $\left[\mathrm{W} / \mathrm{m}^{2}\right]$ \\
\hline$I_{L, r e f}$ & Light current at the reference condition \\
\hline$T_{C}$ & PV cell temperature $\left[{ }^{\circ} \mathrm{C}\right]$ \\
\hline$T_{C, r e f}$ & Reference temperature $\left(25^{\circ} \mathrm{C}\right.$ in this paper $)$ \\
\hline$\mu_{I, S C}$ & Temperature coefficient $\left[\mathrm{A} /{ }^{\circ} \mathrm{C}\right]$ \\
\hline$I_{O, r e f}$ & Saturation current at the reference condition $[\mathrm{A}]$ \\
\hline$e_{g a p}$ & Band gap of the material \\
\hline$N_{S}$ & Number of cells in series of the PV module \\
\hline$q$ & Electron charge \\
\hline
\end{tabular}

$\begin{array}{ll}\alpha_{r e f} & \text { The value of } \alpha \text { at the reference condition } \\ U_{o c, r e f} & \text { Open circuit voltage of the PV module [V] } \\ U_{m p, r e f} & \text { Maximum power point voltage [V] } \\ I_{m p, r e f} & \text { Maximum power point current [A] } \\ I_{S C, r e f} & \text { Short circuit current in reference condition }[\mathrm{A}] \\ q & \text { Electron charge }\left(1.60218 * 10^{-19}\right) \\ A & \text { Ideality factor parameter } \\ K & \text { Boltzmann's constant }\left(1.38066 * 10^{-23}\right) \\ V_{m p} & \text { Voltage at the maximum power point }[\mathrm{V}] \\ I_{m p} & \text { Current at maximum power point }[\mathrm{A}] \\ G & \text { Solar radiation } \mathrm{W} / \mathrm{m}^{2} \\ G_{r e f} & \text { Solar radiation reference }\left(1000 \mathrm{~W} / \mathrm{m}^{2}\right) \\ \mu_{i s c} & \text { Temperature coefficient in short circuit }[\mathrm{A} / \mathrm{k}] \\ C_{P V} & \text { The overall heat capacity area }\left[\mathrm{J} /{ }^{\circ} \mathrm{C} \mathrm{m}^{2}\right] \\ K_{i n, p v} & \text { Transmittance }- \text { absorption product of PV cell } \\ K_{\text {Loss }} & \text { Overall heat loss coefficient }\left[\mathrm{w} /{ }^{\circ} \mathrm{C} \mathrm{m}^{2}\right] \\ T_{a} & \text { Ambient temperature [ }{ }^{\circ} \mathrm{C} \text { ] } \\ A & \text { Effective area of the PV cell/module }\left[\mathrm{m}^{2}\right]\end{array}$

\section{INTRODUCTION}

Consuming photovoltaic energy is increasing from day to day with the growing demand for electrical energy. On the other hand, the cost of this system is very high because of the nonliner output factor of the arrays, using these systems without power electronic converters, and suitable controlling methods in the above interval are not possible. The output factor of these arrays varies based on fluctuating environmental conditions (temperature or irradiation). In addition, in each different essential environmental condition there is a special array point thanks to which we can achieve maximum array power to transfer to the load. There are several control methods for transferring maximum array power, which can be used as:

- Look-up table 
- Perturbation and observation

- Model-based computation

The last method divides in two major categories, CMPPT (based on current) and VMPPT (based on voltage). The techniques used in this paper for obtaining maximum power value are perturbation and observation ( $\mathrm{P} \& \mathrm{O})$. A photovoltaic system usually connects to the network via a DC/DC converter and an inverter. A DC/DC converter is used for detecting the maximum array power point by control strategies. The inverter is normally connected to the network by a transformer, and is controlled by injecting $\mathrm{AC}$ current to the network with the same phase and low harmonic. This paper consists of a twopart investigation, mathematical and simulation, which will be explained in the following part. Finally, results and conclusion are discussed in the last part.

\section{MAthematical InVEstigation OF the Photovoltaic MOdULE}

A photovoltaic module is identical to a solar cell, but has a diode equivalent. Fig.1(a) shows the diode equivalent that includes five parameters. Shunt resistance $\left(\mathrm{R}_{\mathrm{sh}}\right)$ is in parallel to the diode because it is much larger than sires resistance $\left(R_{s}\right)$. Therefore, taking into account the above descriptions, a simplified equivalent circuit of four parameters can be obtained. Fig.2(b) shows the simplified equivalent circuit.

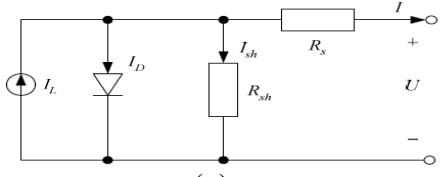

(a)

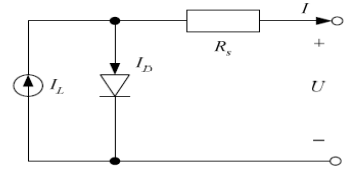

(b)
Fig.1 (a): Five-parameter model; (b) Four-parameter model equivalent circuit for a PV cell

The most important issue with the above circuit is the relationship between output voltage and load current, given below.

$I=I_{L}-I_{D}=I_{L}-I_{o}\left[\exp \left(\frac{U+I R_{S}}{\alpha}\right)-1\right]$

As noted, the four parameters must be calculated before the relationship between voltage and current is obtained. These four parameters include $\mathrm{I}_{\mathrm{L}} \mathrm{I}_{0}$, Rs and $\alpha$. It is clear that the actual solar cell is much more complex than the equivalent equation. For this reason, the above parameters are functions of temperature, solar irradiation or load current. Consequently, the four parameters will be determined next.

\section{A. Light Current $\left(I_{L}\right)$}

According to[1] [2] and [3], $\mathrm{I}_{\mathrm{L}}$ depends on solar temperature and radiation, and is given by:

$I_{L}=\frac{\varphi}{\varphi_{\text {ref }}}\left[I_{L, r e f}+\mu_{I, s c}\left(T_{C}-T_{C, r e f}\right)\right]$

It should be noted that the light current and temperature coefficients are obtained from the factory data sheet.

\section{B. Saturation Current $\left(I_{o}\right)$}

The saturation current is also defined by [4] and [3] and is expressed by the following relation:

$I_{o}=I_{o, r e f}\left[\frac{T_{c, r e f}+273}{T_{c}+273}\right]^{3} \exp \left[\frac{e_{g a p} N_{s}}{q \alpha_{r e f}}\left(1-\frac{T_{c, r e f}+273}{T_{c}+273}\right)\right]$

Moreover, the saturation current at the reference condition can be calculated as:

$I_{O, \text { ref }}=I_{L, \text { ref }} \exp \left(-\frac{U_{O C \text {,ref }}}{\alpha_{\text {ref }}}\right)$

\section{Thermal voltage timing completion factor $(\alpha)$}

According to [2], $\alpha$ is a function that depends on temperature and can be calculated by:

$\alpha=\frac{T_{C}+273}{T_{C, r e f}+273} \alpha_{\text {ref }}$

The reference value of $\boldsymbol{\alpha}$ ref is given by:

$$
\alpha_{\text {ref }}=\frac{2 U_{\text {mp,ef }}-U_{\text {oc, ref }}}{\frac{I_{s, \text { ref }}}{I_{s c, \text { ef }}-I_{\text {mpref }}}+\ln \left(1-\frac{I_{\text {mpref }}}{I_{\text {scref }}}\right)}
$$

\section{Series resistance $(R s)$}

There are different ways to calculate series resistance. Some industry owners provide series resistance value in their documents. However, in this paper, a temperature coefficient of open circuit voltage ( $\left.\boldsymbol{H}_{\text {พซg }}\right)$ is used. This value is also defined in manufacturer documents. According to [3], the proper value is:

$\mu_{v o c}=\frac{\partial_{V_{o c, r e f}}}{\partial_{T_{c, r e f}}}$

This method uses a procedure of limiting the maximum and minimum of series resistance. It is noted that the lower value for Rs must be zero ohm and the upper limit for Rs can be derived based on a practical limit imposed by another cell parameter, $\gamma$ [3]. The Rs maximum value is calculated by:

$R_{s, \max }=\frac{1}{I_{m p, r e f}}\left[\frac{K T_{c, \text { ref }} \gamma}{q} \operatorname{Ln}\left(1-\frac{I_{m p, r e f}}{I_{s c, \text { ref }}}\right)+V_{o c, \text { ref }}-V_{m p, \text { ref }}\right]$

After estimating maximum series resistance, it can be used in the following algorithm to calculate its best value. 


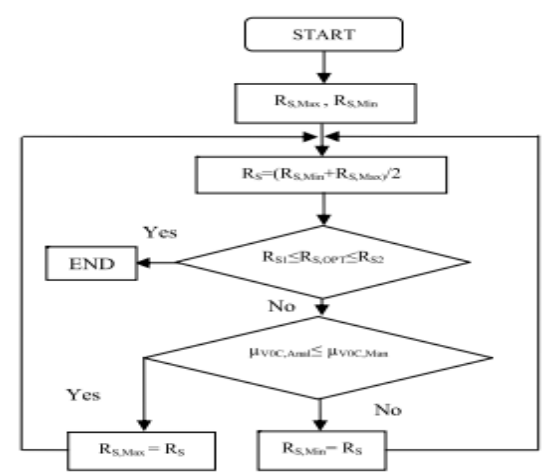

Fig.2: $\mathrm{R}_{\mathrm{s}}$ calculated algorithm [3]

Finally, the above algorithm series resistance can be estimate by:

$R_{S 1}=\left(\frac{V_{m p}}{I_{m p}}+\frac{1}{\lambda I_{m p}}\right) \leq R_{s} \leq\left(\frac{V_{m p}}{I_{m p}}-\frac{1}{\lambda}\left[\frac{1}{I_{L}+I_{o}-I_{m p}}\right]=R_{S 2}\right.$

And

$\lambda=\frac{q}{A K T}$

\section{E. Maximum power parameters $\left(V_{m p}, I_{m p}\right)$}

Forasmuch as the cost of the PV panel is higher than other types of renewable energy, maximum product efficiency is very important. Therefore, according to [3], voltage and current maximum are obtained from the equations below by using the MPPT search algorithm (Fig.3).

$$
\begin{gathered}
V_{m p}=\frac{K \lambda T_{C, r e f}}{q} \operatorname{Ln}\left(\frac{I_{L}-I_{m p}}{I_{o}}+1\right)-I_{m p} R_{S} \\
I_{m p}=\frac{G}{G_{r e f}} N_{P}\left(I_{m p, r e f}+\mu_{i s c}\left(T_{C}-T_{c, r e f}\right)\right)
\end{gathered}
$$

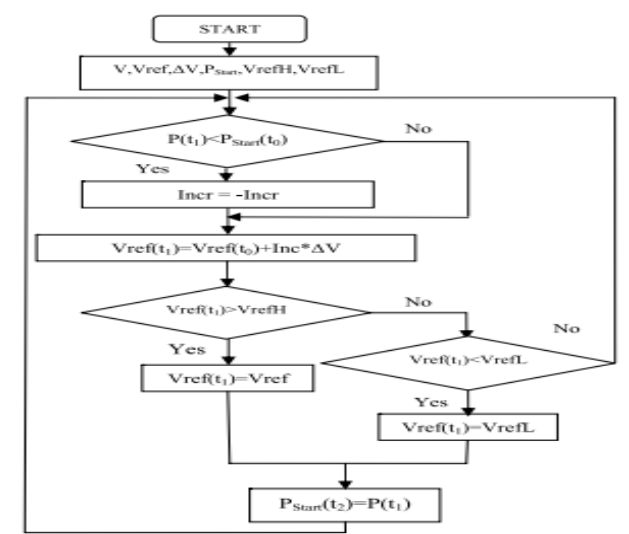

Fig.3: The MPPT search algorithm [3]

\section{F. Thermal model of $P V$}

As in the previous discussion, temperature largely affects PV cell efficiency. Therefore, there is a much-needed thermal module. According to [4], temperature area, irradiance and output voltage, and current have more effect on PV model temperature, so the following equation can be written:

$C_{P V} \frac{\partial T_{C}}{\partial t}=K_{i n, p v} . \varphi-\frac{U \times I}{A}-K_{\text {loss }}\left(T_{C}-T_{a}\right)$

\section{PV PANEL MODELING AND CONTROL}

To model the PV panel all formulas should be simulated in Matlab. However, before explaining the simulation formulas, the PV model block diagram is shown in Fig.4. As shown in (1)-(6) solar irradiation $(\varphi)$, ambient temperature $\left(T_{c}\right)$ and other manufacturing data help to calculate the four parameters. It is noted from Fig.4 that the thermal model determines PV cell temperature, while PV panel output voltage (U), PV cell temperature $\left(\mathrm{T}_{\mathrm{c}}\right)$ and load current (I) are fed back to participate in the calculations.

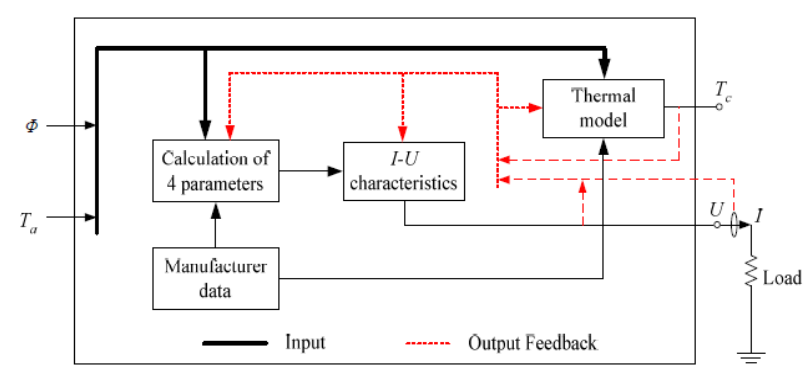

Fig.4: Block diagram of the PV panel in Matlab [4]

\section{A. Four-parameter model}

The model parameters used in the simulation are given in Table 1, based on the values reported by [4]. To explain PV panel simulation, the first step is to use the four-parameter formula previously introduced. Then, light current $\left(\mathrm{I}_{\mathrm{L}}\right)$, saturation current $\left(\mathrm{I}_{\mathrm{o}}\right)$, function of temperature $(\alpha)$ and series resistance $\left(\mathrm{R}_{\mathrm{s}}\right)$, and their simulation are shown.

Table.1 PV panel modeling parameters[2]

\begin{tabular}{cc}
\hline IL,ref (IsC,ref) & $2.664 \mathrm{~A}$ \\
\hline Wref & $5.472 \mathrm{~V}$ \\
$\mathrm{R}_{\mathrm{s}}$ & $1.324 \Omega$ \\
\hline Uoc,ref & $87.72 \mathrm{~V}$ \\
\hline Ump,ref & $70.731 \mathrm{~V}$ \\
Imp,ref & $2.448 \mathrm{~A}$ \\
Xref & $1000 \mathrm{~W} / \mathrm{m}^{2}$ \\
Tc,ref & $25{ }^{\circ} \mathrm{C}$ \\
CpV & $5 \times 104 \mathrm{~J} /\left({ }^{\circ} \mathrm{C} \cdot \mathrm{m}^{2}\right)$ \\
A & $1.5 \mathrm{~m}{ }^{2}$ \\
kin,PV & 0.9 \\
kloss & $30 \mathrm{~W} /\left({ }^{\circ} \mathrm{C} \cdot \mathrm{m}^{2}\right)$ \\
\hline
\end{tabular}


According to (2)-(8) and Table 1 values, the simulation of these formulas by Matlab software is shown below.

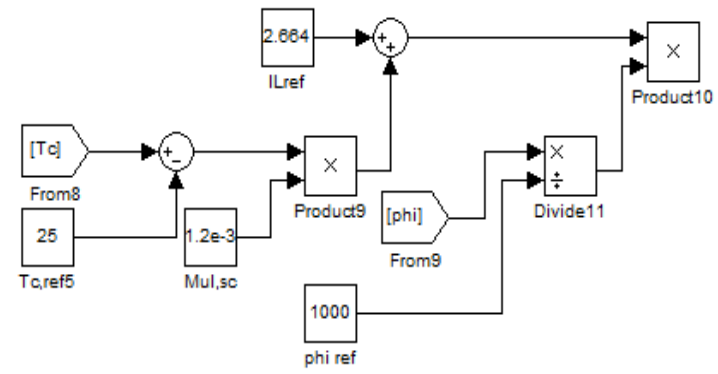

Fig.5: Block diagram of light current simulation

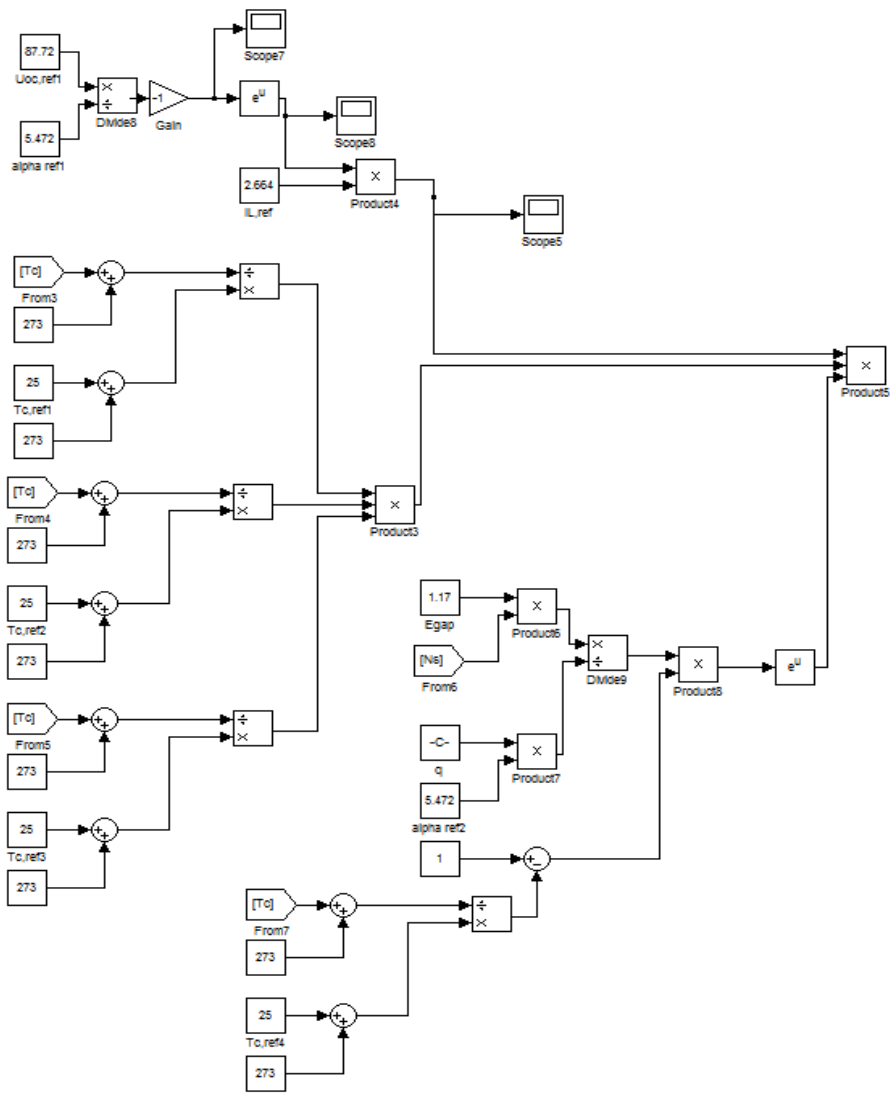

Fig.6: Block diagram of saturation current

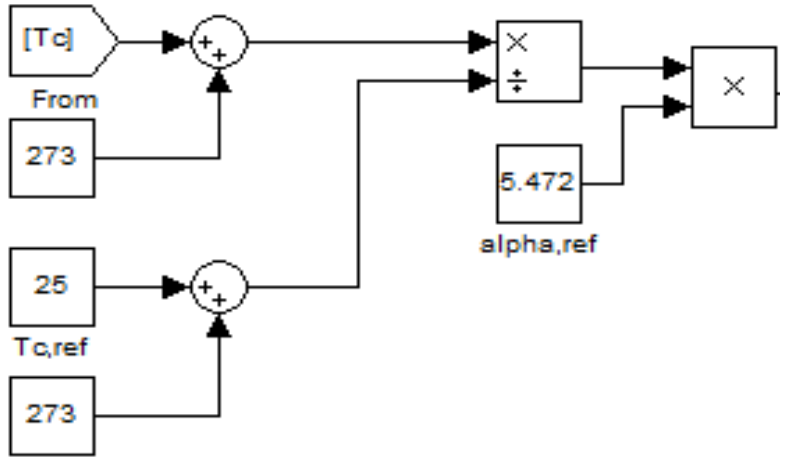

Fig.7: The $\alpha$ block diagram

\section{B. Irradiation and temperature modeling}

According to (13) and Fig.8, the first step was to simulate the PV panel thermal model. Next, temperature increase was defined for the system using a clock. In this part, panel temperature also increased with an increase in area temperature. In addition, in the last part, solar irradiation was defined with the help of a clock over 24 hours. For example, irradiation is zero from midnight until 6 o'clock in the morning, after which irradiation increases parabolic ally.

C. Modeling of maximum current and voltage values (MPPT)

The technique used in this paper for taking the maximum power value is perturbation and observation (P\&O). Fig.10 shows the algorithm diagram of this method. According to the perturbation and observation algorithm shown above and PV panel power generation, MPPT was simulated in Matlab (Fig.11).

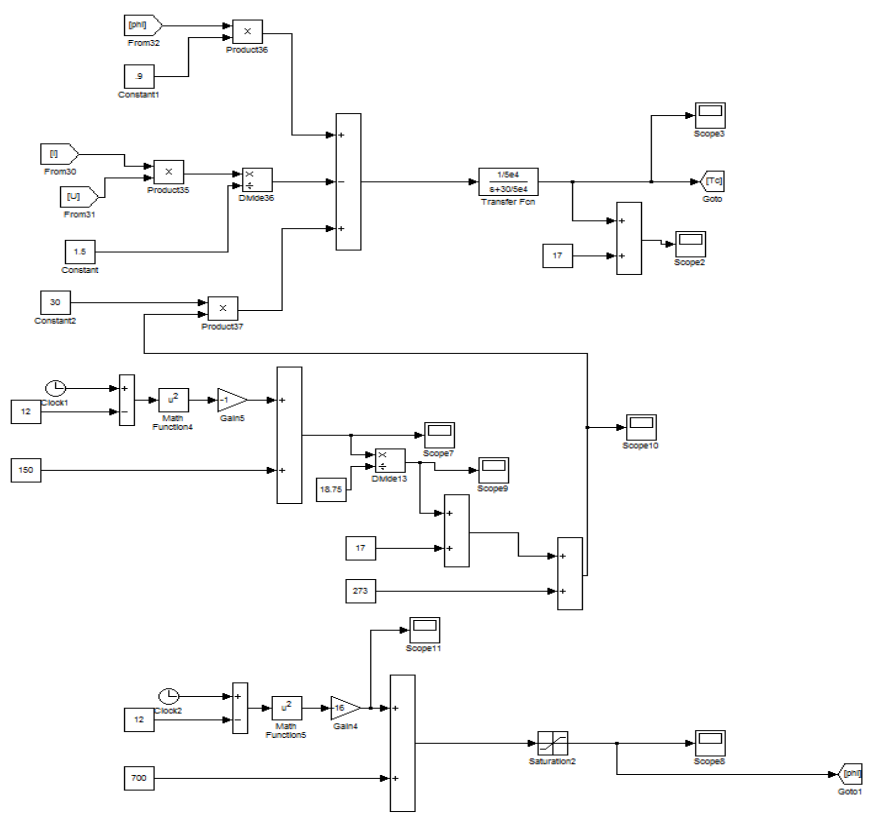

Fig.8: Irradiation and thermal simulation for PV panel

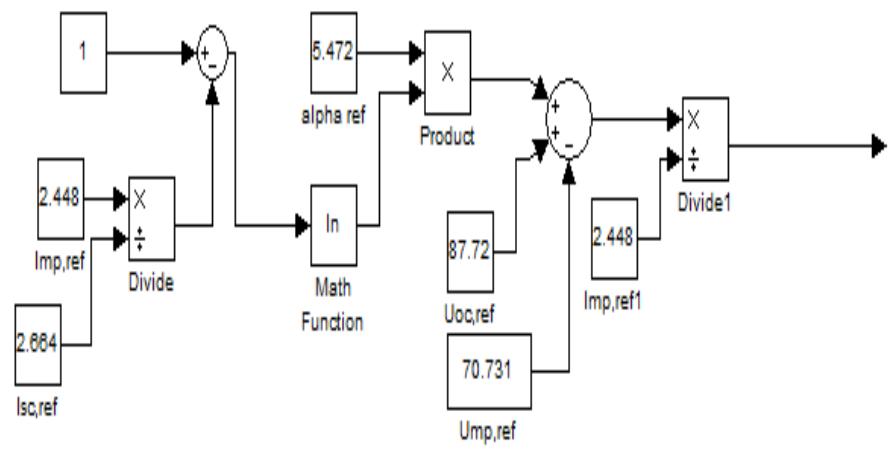

Fig.9: Block diagram of series resistance 


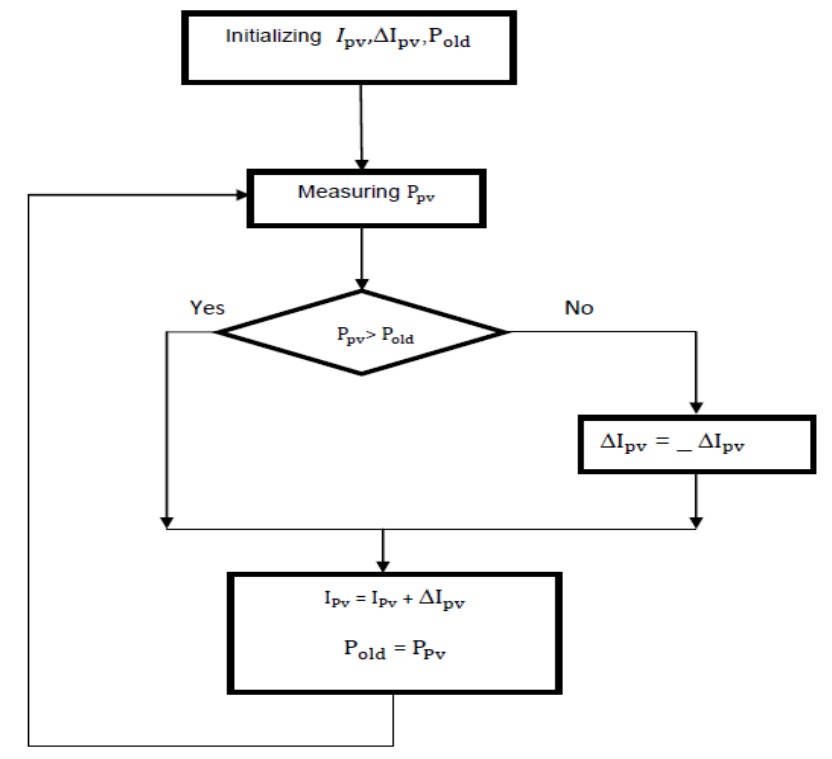

Fig.10: Algorithm diagram of $\mathrm{P} \& \mathrm{O}$ method [3][2]

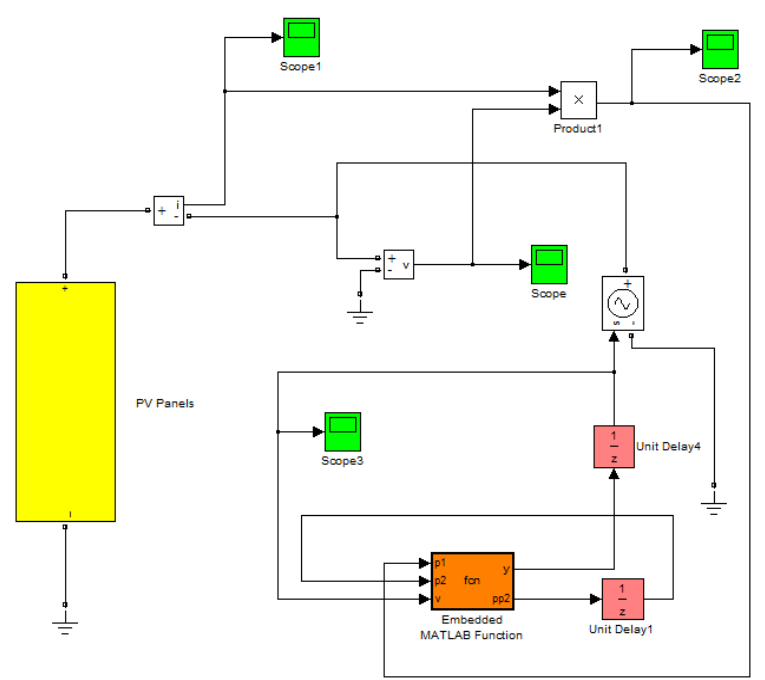

Fig.11: MPPT Simulation in Matlab

\section{RESULTS}

In this part of the PV panel, model curves will be discussed. These curves include I-V and P-V characteristic model, temperature variation, irradiation change and PV panel output power.

\section{A. I-V and P-V characteristic model}

The two most important curves in the photovoltaic panel are Power/Voltage and Current/Voltage. These curves show the relation between temperature, irradiation and power generation. According to Table 1, this consists of PV panel parameters, and Fig.12 (a) and (b) show these curves [2].

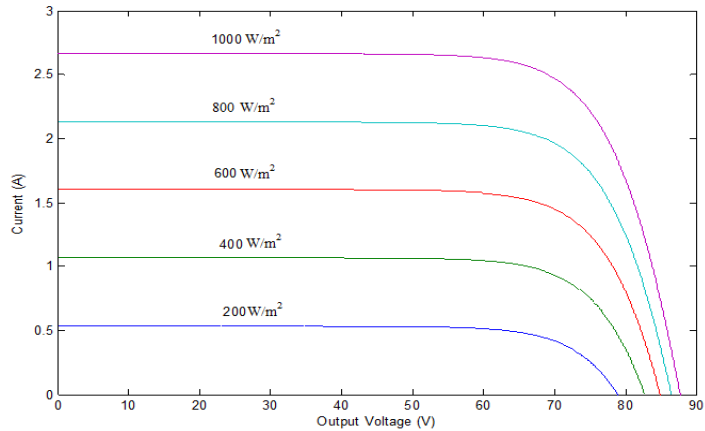

Fig.12 (a): I-V characteristic curves of the PV model at different irradiance values

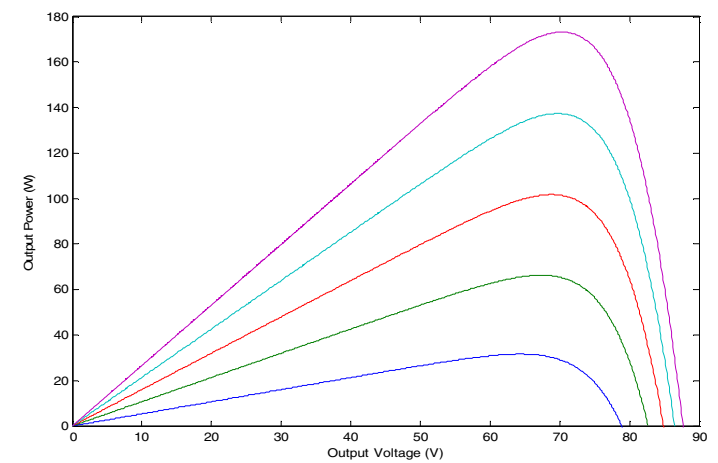

Fig.12 (b): P-V characteristic curves of the PV model at different operating temperatures

\section{B. Temperature and irradiation variation}

A major problem with PV panels is output power variation due to temperature and irradiation changes. It is clear that these parameters will change over the course of a day. For example, during the night, PV panels do not give any solar irradiation and the temperature is low. However, with approaching sunrise, irradiation and temperature manifest a parabolic increase, so in this paper's photovoltaic simulation, irradiation and temperature changes were made for more similarity to reality. Fig. 13 and 14 show the simulated results.

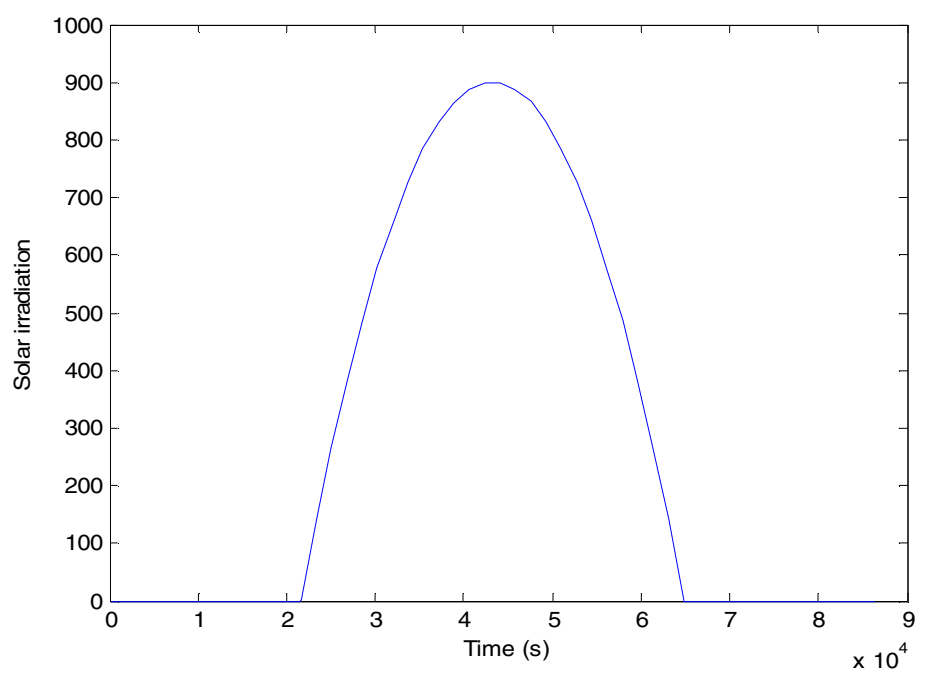

Fig.13: Solar irradiation changes during a day 


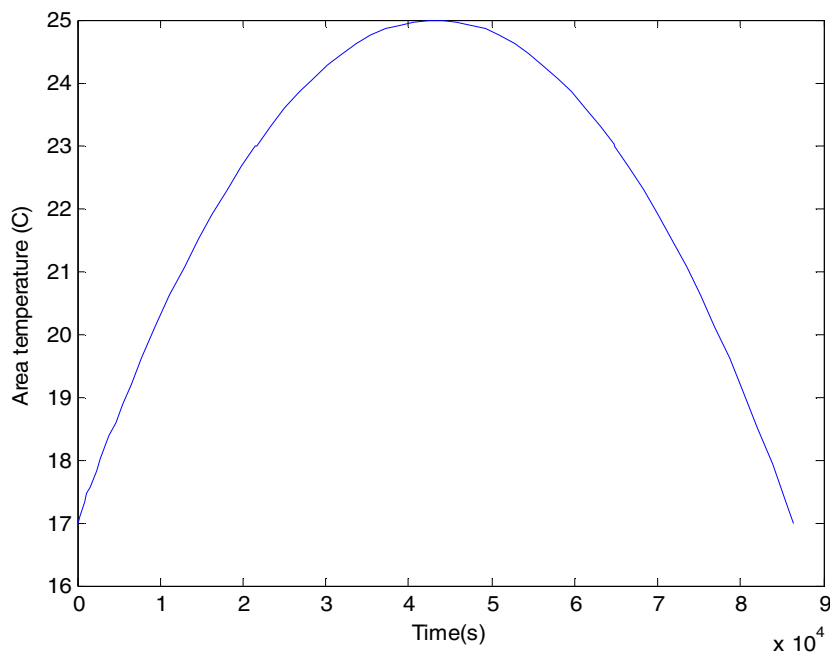

Fig.14: Area temperature changes during a day

\section{Output power generation}

The previous PV panel figures were for ensuring correct operation of the photovoltaic panels. However, the most important aspect regarding PV panels is their output power. Fig.15 also shows that PV panel output power is in direct relation with temperature and irradiation increase.

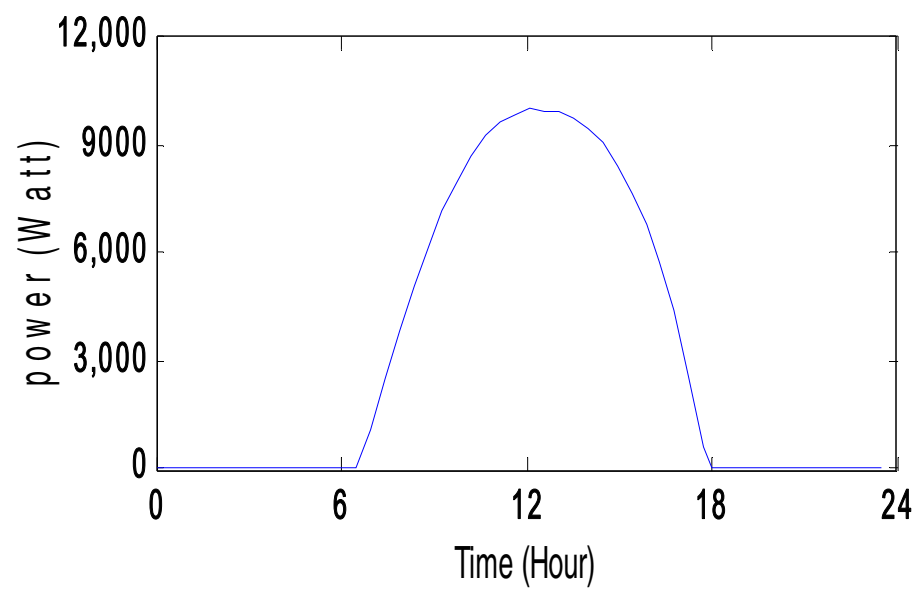

Fig.15: Output power of PV panels during a day

\section{CONCLUSION}

In the first part of this paper, a PV equivalent circuit was simulated by completely investigating a four-parameter model and mathematical equations. Next, from the different maximum power detection methods, the $\mathrm{P} \& \mathrm{O}$ method was investigated and simulated, after which a detector of major current data was applied to receive maximum power. Finally, the MPPT method was applied to the PV equivalent circuit and the whole solar power generation system was investigated.
Reference:

[1] Caisheng Wang, S.M., IEEE, and M. Hashem Nehrir, Senior Member, IEEE, Power Management of a Stand-AloneWind/Photovoltaic/Fuel Cell Energy System. IEEE Transaction on Energy conversion, 2008. 23: p. 3.

[2] Wang, C. and M.H. Nehrir, Power management of a stand-alone wind/photovoltaic/fuel cell energy system. Energy Conversion, IEEE Transactions on, 2008. 23(3): p. 957-967.

[3] Benmessaoud, M., et al., New approach modeling and a maximum power point tracker method for solar cells. Computers \& Mathematics with Applications, 2010. 60(4): p. 1124-1134.

[4] Wang, C., Modeling and control of hybrid wind/photovoltaic/fuel cell disrerbuted generation systems. 2006.

[5] M. E. Ahmed, and S. Mekhilef, "Design and Implementation of a Multi Level ThreePhase Inverter with Less Switches and Low Output Voltage Distortion," Journal of Power Electronics, vol. 9, pp. 594-604, July 2009.

[6] S. Mekhilef, A. M. Omar, and N. Rahim, "Modeling of three-phase uniform symmetrical sampling digital PWM for power converter," IEEE Transactions on Industrial Electronics, vol. 54, pp .427-432, February 2007.

[7] S. Mekhilef, and M. N. Abdul Kadir," Voltage Control of Three-Stage Hybrid Multilevel Inverter Using Vector Transformation," IEEE Transactions on Power Electronics, vol. 25, pp. 2599- 2606, May 2010.

[8] T. S. Ustun, and S. Mekhilef, "Effects of a Static Synchronous Series Compensator (SSSC) Based on Soft Switching 48-Pulse PWM Inverter on the Power Demand from the Grid," Journal of Power Electronics, vol. 10, pp. 85-90, January 2010. S. Mekhilef, and M. N. Abdul Kadir, "Novel Vector Control Method for Three-Stage Hybrid Cascaded Multilevel Inverter," IEEE Transactions on Industrial Electronics, vol. 58, pp. 1339-1349, April 2011.

[10] A. Safari, and S. Mekhilef, "Simulation and Hardware Implementation of Incremental Conductance MPPT with Direct Control Method Using Cuk Converter," IEEE Transactions on Industrial Electronics, vol. 58, pp. 1154 -1161, April 2011.

[11] T. S. Ustun, and S. Mekhilef, “Design and Implementation of Static Synchronous Series Compensator with a soft-switching H-bridge Inverter with DSP-Based Synchronization Control," International Review of Electrical Engineering (IREEE), vol. 5, pp. 1347-1353, July- August 2010. 